\title{
Grundtvig i finländskt perspektiv
}

\section{Af Gustav Björkstrand}

Förgäves söker man i N. F. S. Grundtvigs skrifter belägg för att han skulle ha intresserat sig för Finland i något som helst avseende. Norden, som står centralt i Grundtvigs synfält, det är framför allt de tre kungarikena Danmark, Norge och Sverige. Han kan vidare tala om medeltidens nordiska högskola i Island, »magelös i hele Verden «. ${ }^{1}$ I sin kända skrift $O m$ Nordens videnskabelige Forening från år 1839 nämner han de två äldre universiteten i Uppsala och Köpenhamn och de två yngre i Lund och Christiania och utformar sedan sin grandiosa plan för ett nordiskt universitet som skall överglänsa inte bara Berlin, Göttingen och Wittenberg, utan också »Colosserne« i Paris, Oxford och Cambridge. $^{2}$ Varken den kort därförinnan år 1640 grundade Åbo Akademi, som var ett svenskspråkigt universitet, eller det från Åbo efter stadens brand år 1828 flyttade Kejserliga Alexandersuniversitetet kommer i hans tankar. Incitament som borde ha gett anledning till det saknades inte.

\section{Grundtvig blir korresponderande ledamot}

Den 16 mars 1835 beslöt det fyra år tidigare grundade Finska Litteratursällskapet att till »Utrikes Corresponderande Ledamot« kalla »Pastorn Nik. Fredr. Severin Grnndtvig i Köpenhamn. « ${ }^{3}$ Någon närmare motivering till beslutet framgår inte av protokollet. I en av sällskapet långt senare utgiven verksamhetsberättelse, daterad i mars 1873, förmodar man när man nämner hans bortgång att man ville hedra honom på grund av utgivningen av Nordens Mythologie år 1832. Man betonar också att han blev känd som historiker, diktare och främjare av folkbildningen. ${ }^{4}$

Grundtvig var ingalunda det enda person i Danmark som hedrades på detta sätt. De två första personerna utsedda till »corresponderande medlemmar « var nämligen professor Karl Christian Rafn och professor Christian Molbech, båda kallade den 9 oktober 1833. Grundtvig blev den sjunde i ordningen bland de kallade korresponderande medlemmarna, efter bland andra den från Finland flyttade skalden Frans Mikael Franzén, senare biskop i Härnösand i Sverige. ${ }^{5}$ Intresset för kor- 
responderande medlemmar var vid denna tid ömsesidigt. Så blev t.ex. provinsialläkaren Elias Lönnroth enhälligt utnämnd till »Ordinarie Ledamot « av Kongliga Nordiska Fornskrift-Sällskapet i april $1834{ }^{6}$ Beslutet ställde till stora bekymmer för Lönnroth, som just då höll på med arbetet på den första upplagan av Kalevala. Han måste nämligen vända sig till Litteratursällskapet och be om ett lån på 200 Rubel för att "på engång « kunna erlägga medlemsavgiften till Fornskriftsällskapet $\mathrm{i}$ Köpenhamn. Sällskapet beslöt att »med största nöje« tillmötesgå Lönnroths begäran, »erkännande Doctor Lönnroths stora förtjänster om den Finska Litteraturen. « ${ }^{7}$

Det vanliga var att personer som kallades till korresponderande medlemmar besvarade kallelsen. Så gjorde t.ex. kungliga sekreteraren Adolf Ivar Arvidsson och professor Karl Christian Rafn, som avböjde erbjudandet sannolikt av ekonomiska skäl, eftersom han inte förklarade sig villig att erlägga det i statuterna fastställda bidraget. Han skulle dock ge ett bidrag »en gång för alla « i form av ett parti Nordiska fornskrifter till ett värde av 100 rubel. Medlemsavgiften var då 25 rubel. ${ }^{8}$ Eventuellt kan Grundtvigs uteblivna reaktion bero på hans ekonomiska omständigheter, men det förklarar i varje fall inte att han bara kort senare underlåter att inbegripa Finlands universitet och Finland överhuvud $\mathrm{i}$ den nordiska gemenskapen. Man kunde tänka sig att det finska språket skulle ha varit det avgörande hindret, men vid denna tid skrevs t.ex. alla protokoll i Finska litteratursällskapet på svenska och undervisningspråket vid universitetet var likaså svenska. Grundtvig kan knappast heller ha varit omedveten om det arbete Lönnroth utförde just vid denna tidpunkt när han sammanställde de finska runorna till storverket Kalevala. Man kunde ju ha förväntat sig att de finska runorna, som väckte det Nordiska Oldskriftsällskapets intresse, skulle ha lämnat några spår i Grundtvigs författarskap, men så är inte fallet.

\section{Skandinavismen}

När de akademiska kretsarna i Danmark, Sverige och Norge blev banerförare för skandinavismen riktades intresset bl.a. på Finlands ställning i den nordiska gemenskapen. Både vid det nordiska studentmötet i Stockholm och Uppsala år 1843 och vid mötet i Köpenhamn två år senare var temat aktuellt. Vid det senare mötet slog man resolut fast att man saknade »de finska bröderna« och utropade med ackla- 
mation: »Leve den skandinaviska andan i Finnarnas land! Leve Nordens femte universitet! Helsingfors leve!« Talare vid det mötet var bl.a. Grundtvig och man uppvaktade honom också senare i »Backehuset «, där han bodde. Ännu 1851 var Grundtvig med på den nordiska studentmötet i Norge och blev föremål för en omfattande hyllning. Efter hemkomsten betonade han dock att den nordiska gemenskapen var av andligtkulturellt slag och att folken på det politiska området borde ges full frihet och självständighet. ${ }^{9}$ Också i detta sammanhang kom Grundtvig alltså i kontakt med problematiken kring Finlands ställning i Norden utan att han såvitt det är känt kommenterade frågan på något sätt.

\section{Folkhögskoltanken blir känd i Finland}

År 1868, samma år som de tre första folkhögskolorna grundades i Sverige, blev folkhögskoltanken känd i vidare kretsar också i Finland. Den första artikelserien om skolformen publicerades i tidningen Folkwännen i april, sannolikt författad av tidningens redaktör W. Grefberg. Författaren konstaterade att mången slumrande förmåga skall bli väckt och fostrad till gagn för fosterlandet genom folkskolan när folkhögskolan blev allmänt känd. Men den skolformen kunde ändå aldrig bli mer än »ett slags grofhywlingsanstalt « som avlägsnade den värsta okunskapen. Större resultat kunde man förvänta sig först genom att också ta i bruk den danska folkhögskolan, som enligt författaren kunde anses ha »omätelig wigt « när det gällde att ge en verklig livsupplysning till allmogen. ${ }^{10}$

Autodidakten Anders Svedberg, som grundat en skola på den österbottniska landsbygden i Munsala, rapporterade i Hufvudstadsbladet i augusti 1868 från ett skolmöte i Örebro, där bland annat folkhögskolan var föremål för debatt. Han hävdade att han, utan att känna till folkhögskolan som skolform, hade tillämpat en del av dess principer vid sin skola i Munsala. När han senare i december återkom till frågan, rekommenderade han ett närmande mellan folkskolans och folkhögskolans sätt att arbeta. Vinsten av en sådan förening kunde enligt Svedberg vara att folkhögskolans »mera lif- och själfulla nationella anda « skulle få prägla folkskolan, så att eleverna verkligen skulle väckas »till medvetande af sina rättigheter och skyldigheter « $\mathrm{i}$ ett »älskadt fosterland «. ${ }^{11}$ 
En intressant detalj i sammanhanget är att Svedberg i sina artiklar behandlar frågan om mytologins betydelse när det gäller att väcka ett folks livskraft. För Finlands del var den centrala frågan om man skulle använda sig av den nordiska mytologin eller den "genuint finska folkstammens mythologi «. Svedberg hävdar att hans erfarenhet från skolan i Munsala var att man åtminstone i det svensktalande Finland måste använda de nordiska myterna om man ville väcka åhörarnas intresse och förmedla deras kraft. Han förmodade dock att läget kunde vara ett annat på finskspråkigt håll i landet. ${ }^{12}$ Ifall Grundtvigs medvetna val att lämna Finland utanför sina betraktelser trots att Finland $i$ århundraden varit en helt integrerad del av det svenska riket har sin förklaring i en känsla av främlingsskap inför den finska mytologin, har han alltså en bundsförvant i Anders Svedberg och de erfarenheter han gjorde i sitt skolarbete.

Samma år, 1868, sökte seminariedirektorn K.G. Leinberg, upp Grundtvig under en resa i Danmark. Han presenterade sina erfarenheter i ett föredrag vid Pedagogiska föreningens möte i Helsingfors i september. Han var mycket imponerad av den danska folkhögskolan och fann det »högeligen önskvärdt « att folkhögskolor, »lämpade efter våra förhållanden«, skulle komma till stånd. Vid sitt möte med Grundtvig ställde han frågan om inte en folkhögskolföreståndare som var »lifvad af kristendomens rika och djupa läroinnehåll« ägde en sådan frihet att han fick utlägga detta för eleverna och att man sålunda kunde ha religionsundervisning på folkhögskolans läroplan. Enligt Leinberg gav Grundtvig ett jakande svar, men lät samtidigt förstå att bibeln inte var ett lämpligt läromedel för religionsundervisningen. ${ }^{13}$ Frågan är om Grundtvig verkligen gav ett dylikt svar, eller om han undvek att stöta sig med frågeställaren, men samtidigt distanserade sig genom hänvisningen till bibelns olämplighet som läromedel. ${ }^{14}$ Hur som helst kom Grundtvig alltså även i detta sammanhang i kontakt med framstående företrädare för pedagogiken i Finland. Några spår av detta kan man inte finna hos Grundtvig, vilket naturligtvis också måste ses mot bakgrunden av hans ålder vid denna tidpunkt.

Till dem som tidigt verkade för grundandet av folkhögskolor i Finland hörde professor Y. S. Yrjö-Koskinen, som i artiklar i Kirjallinen Kuukausilehti (Skriftligt månadsblad) betecknade den upplysning som skolformen kunde ge som ett direkt livsvillkor med tanke på den gapande klyfta som fanns mellan tjänstemännen och folket på landsbygden. ${ }^{15}$ Också studenterna visade tidigt ett betydande intresse för folkhögskolan. Frågan togs upp redan år 1869 när man i Västnyländska studentför- 
eningen diskuterade den i närvaro av bl.a. Zacharias Topelius. De österbottniska och tavastländska studentföreningarna var likaså aktiva. ${ }^{16}$ Genom denna verksamhet lades grunden för de initiativ som studentföreningarna tog när folkhögskolor sedan grundades från år 1889 framåt.

\section{Grundtvigs betydelse för finländska folkhögskolpionjärer}

Det faktum att Grundtvig inte visade Finland något intresse betydde inte att man i Finland skulle ha svarat med samma mynt. Snarare är det så att hans inflytande blev minst lika stort i Finland som i de andra nordiska länderna utanför Danmark. Jag har genom en kartläggning av brevväxlingen mellan danska och finländska folkhögskolföreståndare kunnat påvisa att 12 av de första 13 folkhögskolföreståndarna besökte och fick mycket starka intryck inte minst från Askov, men också från andra danska folkhögskolor, bland dem Vallekilde. Det är tydligt att både de finländska folkhögskolpionjärerna och kretsarna bakom planerna på att grunda folkhögskolor fann det angeläget att man fick personliga erfarenheter av vad man ville uppnå med skolformen och hur arbetet skulle bedrivas. ${ }^{17}$ Det är säkert heller ingen tillfällighet att man sökte sig till de folkhögskolor som grundats av medlemmar i Grundtvigs »Lille Theologicum«, dvs. till Askov med Ludvig Schröder, Vallekilde med Ernst Trier och Testrup med Jens Nörregaard.

Grundtvigs namn förekommer ofta i brevväxlingen mellan danska och finländska folkhögskolföreståndare. ${ }^{18}$ Sofia Hagman, som blev den verkliga folkhögskolpionjären i Finland, kom i kontakt med den danska folkhögskolan redan år 1884 vid ett besök i Köpenhamn och återkom efter att bl.a. ha besökt Tärna folkhögskola i Sverige år 1888 till Askov och Vallekilde.

Hon kände sig något främmande inför Triers starkt väckande undervisning och följde i sin egen verksamhet snarare den förebild hon hade fått från Askov. Hon publicerade år 1891 en skrift om folkhögskolan i Danmark (Kansanopistoista Tanskassa) och fick kritik för att hon gav för stort utrymme åt den danska folkhögskolan på bekostnad av övriga nordiska länders erfarenheter. ${ }^{19}$

Hjalmar Mikander, senare föreståndare för Mellersta Savolax folkhögskola, besökte Danmark första gången år 1890 och återkom till Askov läsåret 1891-92. I brevväxlingen med Schröder uppger han att han i Askov fătt ta emot »ädla idéer och väckelse till dessas full- 
bordande «. Kontakten till Danmark upprätthölls också genom litteratur och tidskrifter och sångerna, bland dem Grundtvigs »Hvad solskin er for den sorte muld « sjöngs flitigt i skolan. ${ }^{20}$

Den tydligaste inblicken i hur de finländska folkhögskolpionjärerna upplevde tiden i Danmark ger dock Johannes Klockars, som tillbringade läsåret 1890-91 med att besöka folkhögskolor i framför allt Danmark, men också i Sverige. När han kom hem skrev han till Schröder att »det mesta af hvad Grundtvig skref om skolan för döden, Drengevidenskabeligheden o.s.v. kan nu tillämpas på oss «. Allt ropade enligt Klockars på folkhögskolan: det lägre folkets bokstavstro, det mänskligas och kristligas motsatsförhållande till varandra, klyftan mellan överklass och underklass. Vad folkhögskolfolket i Finland måste betona var »lif framför lära, anda i stället för bokstav, ord framför böcker som ändamål . $^{21}$

Också Robert Rostedt, som vistades på Askov samtidigt som Klockars och som blev den första föreståndaren för Mellersta Nylands folkhögskola, fann anledning att understryka i sina brev att »Grundtvigs planta är acclimatiserad i vårt land. « Även om organisationen i mycket var svensk-finsk, så var andan dansk. Han hävdar vidare att Grundtvig, vars bild hängde på väggen i skolan, kunde känna sig »hemmastadd här «. Det är ju så att »idén är enahanda i grunden, men dess former vid förverkligandet mångfaldiga«. Kontakten till Danmark upprätthölls också här genom kontakten med danska tidskrifter som Danskeren och Höjskolebladet. Rostedts älsklingsång var Grundtvigs Vad solsken är för den svarta mull. ${ }^{22}$

Också de övriga breven ger en klar bild av den betydelse mötet med danska folkhögskolor hade för de finländska folkhögskolpionjärerna. Mot denna bakgrund ter det sig knappast enbart som en artighetsfras när Helmer J. Wahlroos, föreståndare för Borgå folkhögskola, i festskriften till den danska folkhögskolan vid 100-årsjubileet drar en parallell mellan pilgrimernas resor till det heliga landet och folkhögskolpionjärernas resor till Danmark. Han frågar i artikeln om »något annat av de nordiska länderna förutom Danmark så ömt och trofast vårdat det speciellt grundtvigska arvet i folkhögskolan «. ${ }^{23}$ 
Antalet folkhögskolor i Finland steg efter grundläggningsåret 1889 snabbt fram till år 1906 då det uppgick till 24. Av dem var 9 svenskspråkiga. Alla folkhögskolor kan betecknas som grundtvigianska. ${ }^{24}$ Det fanns dock vissa uppenbara skillnader $\mathrm{i}$ relation till den danska traditionen. I de finländska folkhögskolorna hade man kristendomsundervisning på programmet och de praktiska ämnena hade en mer framträdande plats. Fram till landets självständighet år 1917 hade antalet ökat till 42. Av dem var 28 finskspråkiga och 14 svenskspråkiga. $\mathrm{Nu}$ tillkom de första kristliga folkhögskolorna i Helsingfors och södra Österbotten. Det grundtvigianska arvet var fortfarande starkt. I finska folkhögskolor var Kalevalas ställning central - ur den finska mytologin hämtade man inspiration och livsvisdom i äkta grundtvigiansk anda. ${ }^{25}$

Folkhögskolans ställning som en allmän utbildningsenhet för dem som inte hade haft möjlighet att gå i läroverk av ekonomiska eller geografiska orsaker blev med tiden allt mer central och bidrog till att det grundtvigianska inslaget tonades ner till förmån för nyttosynpunkter och rent kunskapsinhämtande. Efter modell från Danmark grundade man folkhögskolor med en andra årskurs - s. k. folkakademier - den första var Svenska folkakademin i Borgå, grundad år 1908. Under självständighetstidens första år etablerades ett stort antal nya folkhögskolor. Det var framför allt de inomkyrkliga väckelserörelserna som gick i spetsen för ansträngningarna. Sammanlagt grundades 13 nya kristliga folkhögskolor och dessutom fick arbetarrörelsen sin första folkhögskola, Työväen Akatemia (arbetarbefolkningens akademi), år 1924. Fram till andra världskrigets utbrott steg antalet folkhögskolor till 54, av vilka 19 var kristliga ${ }^{26}$ Förändringarna innebar att det grandtvigianska inslaget försvagades. De kristliga folkhögskolorna valde en linje som låg närmare Kristen Kolds och arbetarrörelsen hade sin egen ideologi.

Fram till 1968 hade antalet folkhögskolor stigit till 68 egentliga folkhögskolor och 15 s.k. folkakademier, dvs. Folkhögskolor med en andra årskurs. Enligt den finska folkhögskolrörelsens minnestecknare M. O. Karttunen kunde man beteckna 38 av dem som grundtvigianska. Därutöver fanns 5 folkhögskolor med anknytning till arbetarrörelsen och fyra med organisationsbakgrund. ${ }^{27}$ Den andra stora gruppen bestod av de kristliga folkhögskolorna, vilka framför allt syftade till att nå väckelserörelsernas ungdomar och ungdomar utanför denna krets i ett evangeliserande syfte. ${ }^{28}$ Under denna tidsperiod accentuerades ytter- 
ligare behovet att ge ungdomarna en bättre grundutbildning och föreberedelse för yrkesverksamhet. Den tidigare enhetliga läsordningen för alla elever blev allt mer differentierad under beaktande av elevernas individuella behov. Folkhögskolans ideologiska karaktär och grundtvigianska arv trängdes allt mer i bakgrunden.

I slutet av 1970-talet och under förra delen av 1980-talet upplevde man inom folkhögskolkretsar en Grundtvig-renässans. Några folkhögskolrektorer samlades på Oriveden Opisto för att diskutera den grundtvigianska folkhögskolans värdeuppfattning, människosyn och livsfilosofi. Man var överens om att det inte längre var möjligt att förverkliga folkhögskoltanken i grundtvigiansk anda och valde i stället FN:s deklaration om de mänskliga rättigheterna som en gemensam utgångspunkt. Det oaktat spelade Grundtvig-intresset en betydande roll i den nya förenings verksamhet som blev ett resultat av mötet. Föreningen var en sammanslutning för grundtvigianska eller obundna folkhögskolor och antalet folkhögskolor som hörde till den uppgick år 1988 till 24 . Grundtvig-jubileet stimulerade ytterligare Grundtvig-intresset och ett stort antal artiklar om honom publicerades i tidskriften KansanopistoFolkhögskolan under temat Människosynen i de grundtvigianska folkhögskolorna. ${ }^{29}$

Rauno Malviniemi, som har undersökt bakgrundsorganisationerna för de grundtvigianska folkhögskolorna, hävdar i folkhögskolans 100-års festskrift att strömningarna på 1980-talet inte kunde leda till att grundtvigianismen på nytt blev en drivkraft för folkhögskolan. Betydelsen av det nyvaknade Grundtvig-intresset låg i att man fick en fördjupad kunskap om folkhögskolans tradition och ideologiska grundval. De obundna eller grundtvigianska folkhögskolorna - man betonade ibland den ena, ibland den andra aspekten - ville marknadsföra sig som ett öppet forum, där olika människouppfattningar, idéer och världsbilder fick möta varandra. Genomslagskraften för tankegångarna blev dock inte särdeles stor. Eleverna som sökte sig till folkhögskolan på 1980-talet i Finland kom framför allt för att få betyg och poäng med tanke på fortsatta studier i andra skolformer. Yrkesmässig eller yrkesorienterande utbildning fick en rätt stark ställning i folkhögskolan..$^{30}$ Det gångna seklets sista decennium har inte medfört några större förändringar härvidlag. 


\section{Grundtvigs psalmer}

Om man vänder blicken mot andra områden, inom vilka Grundtvigs betydelse har varit stor, spelar hymnologin utan tvekan en central roll. Grundtvigs betydelse för den nordiska psalmskatten kan knappast överskattas. Det tog dock rätt länge innan Grundtvig blev känd i Finland som psalmförfattare. De första finska och svenska psalmböckerna i storfurstendömet Finland utkom år 1886 och innehöll inte en enda psalm av Grundtvig. Förändringen kom först på 1920-talet med de psalmbokstillägg som då utarbetades. I tillägget år 1922 är Grundtvig representerad med hela sex psalmer. Två av psalmerna fick en mera bestående plats i den svenska psalmtraditionen i Finland. Det var Gammal är kyrkan Herrens hus (Kirken den er et gammelt Huus) och Likt vårdagssol $i$ morgonglöd (Som Foraars-Solen morgenrød). De fyra övriga förslagen var inte allmänt accepterande: Det är så ljuvligt att gå åstad (Det er saa yndigt at følges ad), Guds ord från fädren gått i arv (Guds Ord det er vort Arve-Gods), Jesus, störst bland jordens söner (en psalm som uppges vara skriven »efter Bernhard av Clairvaux och Grundtvig «) samt slutligen Underbar en stjärna blid. Under arbetet med 1928 års tillägg ansluts ytterligare två Grundtvig-psalmer, nämligen Där alla vägar sluta (Her mødes alle Veje) och Jesus har grundat ett rike (Stiftet Guds Søn har paa Jorden), till psalmskatten.

I 1943 års svenska psalmbok blev Grundtvig representerad av de fyra tidigare nämnda psalmerna, två från år 1922 och två från år 1928, samt dessutom av tre nya. De nya psalmerna var $O$ liv, som blev tänt $(\mathrm{O}$ Kristelighed) i Emil Liedgrens översättning, Att säga världen helt farväl (At sige Verden ret Farvel) samt Vår Herres Jesu nattvard är (Vor Herres Jesu Mindefest). Den nyaste svenska psalmboken från år 1986 innehåller ytterligare två Grundtvig-psalmer, nämligen Ge mig Gud en lärkas tunga (Giv mig Gud en Psalme-Tunge) och Världen som nu föds på nytt (Verdens Igienfødelse). Sammanlagt har den nya svenska psalmboken alltså nio psalmer av Grundtvig.

På finskspråkigt håll har Grundtvig inte haft samma genomslagskraft. I 1923 års tillägg blev han representerad för första gången med två psalmer, nämligen Vanha on kirkko paikallaan (Kirken den er et gammelt Huus) och Tiet kaikki yhtyy täällä (Her mødes alle Veje). Den finska psalmboken från år 1937 fick ytterligare tre Grundtvig-psalmer, vilka inte är företrädda i motsvarande svenska psalmbok från år 1943. De är Saa ehtoollinen Jeesuksen (Vor Herres Jesu Mindefest), Sinulle 
oi Vapahtaja (Hil dig, Frelser og Forsoner) samt Oi Pyhä Henki pyydämme ( $\mathrm{Nu}$ bede vi den Hellig-Aand). Dessa fem psalmer finns också i den nya finska psalmboken från år 1986. Orsaken till att antalet är betydligt lägre och delvis ett annat än på svenskspråkigt håll står att söka $\mathrm{i}$ att man på svenskspråkigt håll har kunnat tillgodogöra sig översättningar gjorda i Sverige, medan man på finskspråkigt håll har varit hänvisad till de översättningar som har blivit gjorda inom landet. Grundtvig är således, trots att han är den mest representerande psalmförfattaren från Danmark, inte särskilt väl representerad som hymnolog i Finland. Hans psalmer är dock mycket sjungna, särskilt på svenskspråkigt håll. Det är kanske skäl att avslutningsvis notera att ingen psalm från Finland, inte ens Runebergs psalmer, har hittills funnit vägen till den danska psalmboken.

\section{Grundtvigforskningen i Finland}

Grundtvig har inte blivit föremål för någon utförligare analys ur teologisk synvinkel i Finland.

Däremot har man intresserat sig för hans folkhögskoltankar. ${ }^{31} \mathrm{De}$ första folkhögskolföreståndarna gav ut småskrifter om den danska folkhögskolan och om Grundtvig, men den första mer omfattande monografin var skriven år 1929 av Aino Voipio med titeln Grundtvigin nuorisonkasvatusaatteesta (Grundtvigs idé om ungdomens fostran). I boken presenteras först Grundtvig som person och därefter det levande ordet som medel i den historiska undervisningen, principerna för undervisning i det levande ordets skola samt Grundtvigs skoltankar ur en mera systematisk synvinkel. Den första akademiska avhandlingen om folkhögskolan i Finland utgavs år 1936 och gällde folkhögskolidéns utveckling i Finland åren 1868-1892 och var skriven av Matti Wilska. Grundtvig berörs inte mera ingående i den avhandlingen. Det är däremot fallet med den andra akademiska avhandlingen, skriven av Pauli Siljander år 1982. Han behandlar Grundtvigs bildningsidé och folkhögskolans mål för fostran med den finska titeln Grundtvigin sivistysidea ja kansanopiston kasvatustavoitteet. Avhandlingen består egentligen av tre delar, av vilka den sista behandlar Grundtvigs bildningsidé och folkhögskolans uppgift. Rapporterna innehåller också en kort sammanfattning på engelska. Författaren konstaterar bland annat att folkhögskolan i Finland har avlägsnat sig från Grundtvigs ursprungliga 
syn på folkhögskolans uppgift genom att den har inordnat sig i skolsystemet med dess läroplaner och examina.

Folkhögskolan i Finland har naturligt nog varit föremål för en rad historiska skildringar. M. O. Karttunén har skrivit den mest omfattande historiken i ämnet. Därtill finns det en mängd historiker över enskilda folkhögskolor. I en kortare monografi Den finlandssvenska folkhögskolan och allmogemobiliseringen (1981) har jag sökt svaret på frågan varför man i det svenska Finland har grundat 3-4 gånger fler folkhögskolor per invånare än i det övriga Norden inklusive Danmark, dvs. En folkhögskola per 17000 invånare. Svaret blev att den svenska folkhögskolan i Finland med sina 17 folkhögskolor har fyllt tre särskilda uppgifter. Man har försökt väcka allmogen till kamp mot förryskningen, till kamp för det svenska språket och den svenska kulturen och slutligen till kamp mot sekulariseringen och för kristna värden bland ungdomen. I en rad artiklar har jag behandlat Grundtvigs folkhögskolsyn och folkhögskoltanken, särskilt den kristna folkhögskolrörelsens ideologi. ${ }^{32}$ Den sista akademiska avhandlingen i ämnet kom 1999 och behandlar folkhögskolverksamheten i norra Karelen. Den är skriven av Vesa Tuominen och har publicerats i Joensuu universitets pedagogiska serie. Grundtvigs folkhögskoltankar behandlas endast kortfattat - huvudintresset koncentreras till folkhögskolplanerna i denna del av Finland.

Finland har med sina 91 folkhögskolor på en befolkning på drygt fem miljoner gett påfallande stort utrymme åt folkhögskolan som skolform. Denna imponerande utveckling kunde komma till stånd utan att Grundtvig i något som helst avseende engagerade sig för Finland, vare sig när han blev kallad till korresponderande medlem i Finska litteratursällskapet eller senare när skandinavismen växte sig stark och Finlands sak blev en angelägenhet för de studenter han talade till. Hans folkhögskoltankar blev väl kända i Finland och i synnerhet folkhögskolpionjärerna såg det som en nödvändighet att på ort och ställe stifta bekantskap med den skolform i vars tjänst de sedan skulle utföra sin livsgärning.

Särskilt i äldre tider i den finländska folkhögskolans historia var man angelägen om att inte bara hänvisa till behovet av ökad kunskap och bildning, utan också till vikten av att ta vara på de centrala dragen i Grundtvigs syn på den skola för livet som han ville skapa. Genom den betydelse Kalevala med sin mytologi hade för finska folkbildningsträvanden under 1800-talets senare del kom man i Finland att mer troget än på andra håll i Norden hålla arvet efter Grundtvig levande. Små- 
ningom kom dock de reella behoven i samhället och de ekonomiska villkoren att driva skolformen i en mera nyttobetonad och på konkreta examina inriktad bana. Intressant nog fick vi i Finland en ny Grundtvigvåg i slutet av 1970- och början av 1980-talet. Den kunde dock inte driva utvecklingen tillbaka, men bidrog till att hålla Grundtvigs ursprungliga idéer levande inom folkhögskolrörelsen. Någon mer ingående Grundtvigforskning har inte förekommit i Finland. Vid sidan av två akademiska avhandlingar rörande folkhögskolidéns utformning i Finland och Grundtvigs folkbildningsidé föreligger endast mer kortfattade monografier och ett större antal artiklar. Grundtvig har inte intresserat finländska teologer i någon större utsträckning. Däremot är han representerad också i de nyaste svenska och finska psalmböckerna i vårt land. Eftersom psalmerna är mycket sjungna, kommer Grundtvig att vara ett känt namn inte bara för folkhögskolrörelsens folk, utan också för församlingsmedlemmarna i de lutherska församlingarna.

\section{KÄLLOR OCH LITTERATUR}

\section{Otryckta källor}

Helsingfors

Finska litteratursällskapets arkiv (FSLA)

Finska litteratursällskapets protokoll 1835, 1870-1871

Finska litteratursällskapets namnförteckning (Suomalaisen Kirjallisuuden Seuran Nimikirja. Tiedustus-Jäsenet)

Brev och diplom från Det Kongliga Nordiska Oldskrift Selskab 


\section{Anförd litteratur}

Björkstrand Gustav

1978 a Askov och finländska folkhögskolpionjärer. Kristen fostran i kyrka och skola. Rapporter från Pedagogiska fakulteten 6/1978. Vasa.

1978 b Skolan för livet. Huvuddrag i Grundtvigs pedagogiska tänkande. -

Kristen fostran i kyrka och skola. Rapporter från Pedagogiska fakulteten 6/1978. Vasa.

1981 a Denfinlandssvenskafolkhögskolan och allmogemobiliseringen. Kyrkohistoriska arkivet vid Åbo Akademi. Meddelanden 10. Åbo.

$1981 \mathrm{~b}$

Johannes Nyström. Folkhögskolföreståndaren på Himmelsbacken. Vasa.

1983 a

Fädernearv och framtidstro. Den nordiska kristliga folkhögskolan inför 1980-talet. Kyrkohistoriska arkivet vid Åbo Akademi. Meddelanden 16. Åbo.

1983 b

Grundtvig i Finland. Grundtvigs oplysningstanker og vor tid. Nordisk folkhögskolråd. Jelling.

$1983 \mathrm{c}$

Anders Svedbergs livssyn. Fädernearvoch framtidstro. Kyrkohistoriska arkivet vid Åbo Akademi. Meddelanden 16. Åbo.

Grundtvigs skoleverden i tekster og udkast. Bind II. Udgivet af Knud Eyvin Bugge 1968. København.

Huldén J. J.

1932

Anders Svedberg. Skolman Tidningsman Lantdagsman. Helsingfors 
Karttunen M. O.

1979

Suomen kansanopisto 1889-1979. Helsinki.

Leinberg K. G.

1868

Om Folkhögskolorna i Danmark. Helsingfors

Malviniemi Rauno

1989

De grundtvigianska folkhögskolornas bakgrundsorganisationer. - Frihet och anpassning. Hundra år av folkhögskolverksamhet i Finland. Valkeakoski.

Pontoppidan Thyssen Anders

1983

Grundtvigs tanker om kirke og folk. Indtil 1824. 182547. 1848-72.

Grundtvig og grundtvigianismen i nyt lys. Hovedtanker og udviklingslinier fra senere års Grundtvigforskning. Århus.

Skovmand Roar 1983

Samspillet mellem Nordens Folkehøjskoler indtil Anden Verdenskrig.

Skrifter udgivet af Jysk Selskab for Historie 41. Aarhus.

Strömborg Signe

1932

Anders Svedberg. En folkets man. Vasa.

Tiensuu Kyllikki

1983

De kristliga folkhögskolorna i Finland. Frihet och anpassning. Hundra år av folkhögskolverksamhet $i$ Finland. Valkeakoski.

Tuominen Vesa

1999

»Käy hehkuvin rinnoin, mielin puhtain... « Kansanopistohankkeet Pohjois-Karjalassa vuosina 1890-1934. Joensuun yliopiston kasvatustieteellisiä julkaisuja N:o 47. Diss. Joensuu. 
Wahlroos H. J.

1944

Hilsen fra Finland. Danmarks folkehøjskole 1844-1944. København.

Wilska Matti

1937

Kansanopistoaatteen kehitys Suomessa vuosina 18681892.

Suomalaisen kirjallisuuden seura. Diss. Helsinki.

Voipio Aino

1929

Grundtvigin nuorisonkasvatusaatteesta. Helsinki.

Zetterberg Kent 1999

Sverige och drömmen om Finland och Norden under 1800-talet. Reflexioner om skandinavismen, det nationella uppvaknandet i Finland och Sveriges relationer till Finland och Ryssland. - Det hotade landet \& det skyddade. Sverige och Finland från 1500-talet till våra dagar. Södertälje.

\section{Tidningar och tidskrifter}

Folkwännen 1868

Hufvudstadsbladet 1868

Kansanopisto-Folkhögskolan 1978-1983

\section{Noter}

1 Grundtvigs skoleverden 1968 II, 160. Redan i inledningen till skriften preciserar Grundtvig vad han menar med Norden. "Nordens eller rettere sagt: de tre Nordiske Rigers Forening har siden Dronning Margrethes Dage været en Yndlings-Tanke baade hos Grand-Folkene og deres Fyrster”. Grundtvigs skoleverden 1968 II, 126.

2 Grundtvigs skoleverden 1968 II, 140.

3 Finska litteratursällskapets protokoll 16.3.1835 § 10. FSLA.

4 Suomalaisen Kirjallisuuden Seuran keskustelemukset 1870-1871, 162. 
Suomalaisen Kirjallisuuden Seuran Nimikirja. Tiedustus-Jäsenet 1-7. FSLA.

Brev och diplom från Det Kongliga Nordiska Oldskrift Selskab. FSLA.

7

Finska litteratursällskapets protokoll 1.4. $1835 \S 8$. FSLA.

8

Finska litteratursällskapets protokoll 4.2. $1835 \S 2$. FSLA.

Pontoppidan Thyssen 1983, 273; 1983, 340; Zetterberg 1999, 103.

Art. Om Bondehögskolor i Folkwännen $1868 \mathrm{nr}$ 14-18, särskilt artiklarna I och V. Jfr Björkstrand 1981 a, 1.

11 Art. Brev från Swerige i Hufvudstadsbladet 3/8, 7/8, 8/8, 10/8, 12/8 och 13/8 1868 . Folkhögskolan behandlas speciellt i artiklarna 6-8/8 1868. Se vidare art. Folkhögskolan i dess tillämpning i vårt land, Hufvudstadsbladet $8 / 12$ och $9 / 12$ 1868. Till Svedberg, se Huldén 1932; Strömborg 1932, Björkstrand 1983 c.

Art. Folkhögskolefrågan i dess tillämpning på wårt land, Hufvudstadsbladet $9 / 12$ 1868. Jfr Björkstrand 1981 a, 2.

Leinbergs föredrag publicerades med titeln Om Folkhögskolorna i Danmark 1868, mötet med Grundtvig s. 10-11. Jfr Björkstrand 1981 a, 1, 24-25.

14 Till Grundtvigs tankar om kyrka och folk under de sista åren, se t.ex. Pontoppidan Thyssen 1983, 355-359. I sitt brev till Peter Larsen Skræppenborg år 1854 säger Grundtvig att gudsfruktan och fosterlandskärlek inte är »skolesager, da de ikke er noget, man kan lære sig til eller give Folk ind med Skeer, men det er ligefuldt kun en meget daarlig Skole, hvor man enten taber disse Hjertesager af Syne eller stiller dem i et skiævt Lys«. Grundtvigs skoleverden 1968 II, 279. Grundtvig uttalade sig också positivt om Kolds folkhögskolarbete vid ett möte i Köpenhamn i september 1866, vilket visar att han i varje fall hade förståelse för den utformning Kold gav folkhögskolan. Björkstrand 1981 a, 24.

Se härtill Tuominen 1999, 50.

Malviniemi 1989, 21-22.

Björkstrand 1978 a, 58-70. Jfr Skovmand 1983, 83-99.

18 I min artikel Askov och de finländska folkhögskolpionjärerna (1978 a) har jag analyserat den brevväxling som finns bevarad på kungliga biblioteket i Köpenhamn. Se också härtill Skovmand 1983, 83-99. 
20

21

22

23

24

25

26

27

28

29

30

31

32

Björkstrand 1978 a, 62.

Björkstrand 1978 a, 63-64; Skovmand 1983, 90-95.

Björkstrand 1978 a, 64-65; Skovmand 1983, 92-94.

Wahlroos 1944, 535-537.

Karttunen 1979, 43-44; Björkstrand 1981 a, 11, 18.

Karttunen 1979, 62-74.

Karttunen 1979, 104.

Karttunen 1979, 206-207.

Björkstrand 1981 a, 24-32; Björkstrand 1983 a, 1-14; Tiensuu 1989, 49-65.

Malviniemi 1989, 21-37; Björkstrand 1983 a, 103-104.

Malviniemi 1989, 32-35.

En förklarande litteraturöversikt finns i Björkstrand 1983 b, 124-127.

Se härtill anförd litteratur i litteraturförteckningen. Därtill har jag gett ut en biografi om folkhögskolföreståndaren Johannes Nyström. Björkstrand 1981 b. 